\title{
PENGARUH SUHU TERHADAP DERAJAT PENETASAN TELUR IKAN MASKOKI Carassius auratus (Linnaeus, 1758)
}

\section{EFFECT OF TEMPERATURE AGAINST THE HATCHING RATE OF GOLDFISH Carassius auratus (Linnaeus, 1758)}

\author{
HELENTINA MARIANCE MANULLANG \\ Fakultas Perikanan Universitas Dharmawangsa Medan, Jl. KL Yos Sudarso No. 224 Medan, Indonesia \\ `Email : manullanghelen@gmail.com
}

\begin{abstract}
Abstrak. Penelitian ini bertujuan untuk mengetahui pengaruh suhu terhadap derajat penetasan telur ikan maskoki Carassius auratus (Linnaeus, 1758), dan untuk mengetahui suhu terbaik yang menghasilkan derajat penetasan tertinggi ikan maskoki. Penelitian dilaksanakan di Laboratorium Basah Fakultas Perikanan Universitas Dharmawangsa. Penelitian ini menggunakan metode eksperimen dengan rancangan acak lengkap dengan 4 taraf perlakuan dan 3 ulanagan. Berdasarkan hasil analisis variansi diperoleh bahwa perlakuan suhu memberikan pengaruh sangat nyata terhadap derajat penetasan telur ikan maskoki. Hasil analisis variansi menunjukkan bahwa perlakuan suhu berpengaruh sangat nyata (Highly Significant), terhadap derajat penetasan ikan mas koki. Berdasarkan Uji Least Significant Difference (LSD), perlakuan terbaik adalah suhu $30^{\circ} \mathrm{C}$ dengan derajat penetasan sebesar $93,67 \%$.
\end{abstract}

Keywords : Suhu, Derajat Penetasan, Telur Ikan Maskoki

\begin{abstract}
The research aims to determine the influence of temperature against the degree of hatching rate of goldfish (Carassius auratus Linneaeus, 1875), and to find out the best temperatures that produce produce the highest hatching rate of goldfish. Research carried out in the wet laboratory of the fisheries Faculty of Dharmawangsa University. The study uses experimental methods with a randomized design complete with 4 treatment levels and 3 reflications. Analysis of variance results showed that the effect of temperature treatment is Highly Significant, against the goldfish hatchery degree. Based on test Least Significant Difference (LSD), the best treatment is the temperature $30^{\circ} \mathrm{C}$ with the hatchery degree of $93.67 \%$.
\end{abstract}

Keywords : Temperature, Hatching Rate, Goldfish Egg

\section{Pendahuluan}

Ikan hias merupakan komoditas perikanan yang potensial untuk dikembangkan, karena selain mempunyai potensi sumberdaya yang berlimpah juga peluang pasar yang besar, baik di dalam negeri maupun di luar negeri. Indonesia memiliki berbagai jenis ikan hias air laut maupun air tawar yang merupakan suatu keunggulan komparatif. Hingga saat ini perkembangan budidaya ikan hias yang ada di Indonesia mengalami kemajuan yang terus meningkat terutama ikan hias air tawar. Oleh karena itu, diperlukan penanganan khusus pascapanen sehingga produk akuakultur tersebut tetap hidup dan bermutu tinggi ketika sampai ke tangan konsumen. Salah satu jenis ikan hias yang punya nilai ekonomis adalah ikan masa koki (Carassius auratus Linnaeus, 1758).

Menurut [1] ikan maskoki merupakan salah satu jenis ikan hias yang sangat digemari masyarakat serta memiliki nilai ekonomis yang sangat tinggi. Namun derajat penetasan dan pertumbuhan ikan mas koki sangat rendah. Kondisi ini akan mengakibatkan jumlah produksi ikan mas koki yang berkualitas bagus sangat sedikit yang akan berakibat rendahnya produksi 
dari setiap siklus dan turunnya nilai jual ikan mas koki sehingga akan menyebabkan kerugian secara ekonomi di petani ikan hias. Oleh karena itu perlu dicari metode yang dapat digunakan dalam meningkatkan kualitas serta produktivitas ikan mas koki [2]. Dari beberapa penelitian suhu diketahui dapat meningkatkan derajat penetasan telur ikan. Namun suhu optimal untuk penetasan telur ikan mas koki yang terbaik belum diketahui. Hal ini dijelaskan [3] salah satu parameter lingkungan yang berpengaruh signifikan terhadap daya tetas, dan perkembangan larva ikan adalah suhu. Selanjutnya menurut [4] suhu media berpengaruh penting terhadap derajat penetasan telur.

Suhu yang terlalu tinggi atau terlalu rendah dapat menghambat proses penetasan, bahkan suhu yang terlalu ekstrim atau berubah secara mendadak dapat menyebabkan kematian embrio dan kegagalan penetasan. Berdasarkan hal tersebut, penulis tertarik untuk meneliti pengaruh suhu terhadap derajat penetasan telur ikan maskoki.

\subsection{Tujuan Penelitian}

1. Mengetahui pengaruh suhu terhadap derajat penetasan telur ikan maskoki (Carassius auratus, Linnaeus, 1758).

2. Mengetahui rata-rata derajat penetasan telur ikan maskoki (Carassius auratus, Linnaeus, 1758).

\subsection{Manfaat}

1. Sebagai informasi bagi para pembudidaya dalam upaya untuk meningkatkan produksi benih ikan maskoki (Carassius auratus Linnaeus, 1758).

2. Sebagai informasi bagi instansi terkait (terutama Dinas Perikanan dalam peningkatan pengelolaan ikan maskoki di Indonesia, terutama di Propinsi Sumatera Utara).

\section{Bahan dan Metode}

\subsection{Waktu dan Tempat Penelitian}

Penelitian dilaksanakan dari tanggal 12 - 16 Agustus 2019 yang dilaksanakan di Laboratorium Basah Fakultas Perikanan Universitas Dharmawangsa di Jl. Komondor Laut Yos Sudarso Nomor 224 Medan.

\subsection{Bahan dan Alat Penelitian}

\subsubsection{Bahan}

- Induk ikan maskoki 1 pasang yang telah matang gonad

- Telur ikan maskoki sebanyak 1.200 butir.

- Wadah berupa toples sebanyak 12 buah

\subsubsection{Alat}

Peralatan yang digunakan di dalam penelitian ini adalah :

- Thermometer 1 buah untuk mengukur suhu air media.

- $\quad$ pH meter 1 buah digunakan untuk mengukur pH air media.

- Heater untuk penstabil suhu sesuai perlakuan 
- 1 set aerator digunakan untuk airasi air media sebagai pemenuhan oksigen terlarut.

- 2 buah baskom plastik digunakan untuk wadah menghitung benih.

- 1 buah sendok untuk menghitung benih

- 1 buah kamera untuk dokumentasi

\subsection{Hipotesis}

Hipotesis dalam penelitian ini adalah :

$\mathrm{H}_{\mathrm{o}}$ : Tidak ada pengaruh pemberian suhu berbeda terhadap derajat penetasan telur ikan maskoki

$\mathrm{H}_{\mathrm{a}}$ : Ada pengaruh pemberian suhu berbeda terhadap derajat penetasan telur ikan maskoki

\subsection{Metode Penelitian}

Metode penelitian yang digunakan adalah metode percobaan, dengan menguji secara langsung perlakuansuhu berbeda terhadap derajat penetasan telur ikan maskoki.

\subsubsection{Rancangan Percobaan}

Penelitian ini menggunakan Rancangan Acak Lengkap (RAL) pola Non Faktorial karena memakai 1 faktor perlakuan dan nilainya berubah-ubah. Jumlah taraf pada faktor perlakuan suhu terdiri dari 4 taraf yaitu:

1. $\mathrm{A}=$ Perlakuan suhu $27^{\circ} \mathrm{C}$

2. $\mathrm{B}=$ Perlakuan suhu $28^{\circ} \mathrm{C}$

3. $\mathrm{C}=$ Perlakuan suhu $29^{\circ} \mathrm{C}$

4. $\mathrm{D}=$ Perlakuan suhu $30^{\circ} \mathrm{C}$

Masing-masing perlakuan akan mendapatkan ulangan sebanyak 3 (tiga) kali. Sehingga diperlukan wadah percobaan sebanyak 12 wadah, yang penempatannya dilakukan secara acak terhadap semua wadah pengamatan.

Mengingat banyaknya faktor yang dapat mempengaruhi kelulusan hidup benih ikan mas, maka dalam percobaan ini dibuat beberapa asumsi, yaitu :

1. Kualitas telur ikan maskoki pada setiap wadah perlakuan adalah sama.

2. Kondisi lingkungan di sekitar wadah percobaan sama.

3. Ketelitian selama penanganan telur ikan pada masing-masing wadah perlakuan adalah sama

\subsubsection{Prosedur Penelitian}

1. 12 wadah yang akan digunakan untuk penelitian terlebih dahulu dibersihkan (disucihamakan) dengan memakai sabun deterjen, lalu dibilas dengan air tawar kemudian dikeringkan.

2. Wadah-wadah lalu diletakan secara acak setelah diisi air sebanyak 2 liter per wadah.

3. Sebelum telur dimasukan ke dalam wadah maka dipasang terlebih dahulu heater dan aerator untuk suplai oksigen.

4. Selanjutnya telur ikan maskoki dimasukan ke dalam wadah penelitian sesuai dengan perlakuan dan ulangannya (100 butir per wadah)

5. Pengukuran kualitas air berupa, suhu dan $\mathrm{pH}$ dilakukan setiap hari.

6. Penghitungan jumlah telur yang menetas setelah 2 hari. 
7. Memasukan data ke dalam tabel untuk ditabulasikan.

\subsection{Pengumpulan Data}

Data yang dikumpulkan meliputi derajat penentasan telur ikan maskoki yaitu dengan menghitung benih ikan maskoki yang masih hidup. Hasil penghitungan jumlah benih ikan mas dijadikan sebagai data hasil pengamatan yang kemudian diolah dengan cara mentabulasikannya terlebih dahulu, kemudian mengkonversikannya ke dalam bentuk persentase. Menurut [5] untuk mencari daya tetas telur (Hatching Rate) dengan menggunakan rumus sebagai berikut :

$$
\text { Derajat Penetasan }=\frac{\text { Jumlah telur yang dibuahi (ekor) }}{\text { Jumlah telur yang dibuahi }} \chi 100 \%
$$

Data yang dikumpulkan adalah parameter kualitas air meliputi : suhu, dan $\mathrm{pH}$.

\subsection{Analisis Data}

\subsubsection{Validasi Data}

Analisis data hasil pengamaatan dilakukan dengan Analisis Variansi (ANAVA) dan memenuhi syarat-syarat yang digunakan maka dilakukan uji homogenita ragam galat dan mengunakan sebaran chi-kuadrat dengan rumus sebagai berikut:

$X^{2}$ empirik $=2,3036\left\{\Sigma\left(r_{i}-1\right) . \log S^{2}-\Sigma\left(r_{i}-1\right) \cdot \log S_{i}^{2}\right\}$

$\mathrm{X}^{2}$ murni $=\left(\frac{1}{c}\right) \cdot \mathrm{X}^{2}$ empirik

\subsubsection{Analisis Variansi}

Analisis variansi dilakukan berdasarkan rancangan percobaan acak kelompok dengan model linier bersifat additif sebagai berikut :

$$
\mathbf{Y}_{\mathrm{ij}}=\mu+\tau_{\mathrm{l}}+\varepsilon_{\mathrm{ij}}
$$

Dimana :

$\mathrm{Y}_{\mathrm{ij}}=$ Total nilai pengamatan derajat tetas telur ikan maskoki ke 1,2,..12 yang dikenai perlakuan perlakuan suhu berbeda yaitu, $27,28,29$, dan $30^{\circ} \mathrm{C}$

$\mu \quad=$ Nilai rata-rata dari total jumlah nilai pengamatan derajat penetasan telur ikan maskoki

$\tau_{1} \quad=$ Nilai pengamatan derajat penetasan telur ikan maskoki yang disebabkan pengaruh pemberian perlakuan suhu yang berbeda.

$\varepsilon_{i j} \quad=$ Nilai eror percobaan dalam unit percobaan yang disebabkan oleh faktor nonperlakuan yang timbul pada unit-unit percobaan ke $1,2, \ldots 12$ yang dikenai perlakuan pemberian suhu berbeda terhadap derajat penetasan telur ikan maskoki. 


\section{Hasil dan Pembahasan}

\subsection{Derajat Penetasan Telur}

Berdasarkan data hasil penelitian menunjukkan bahwa derajat penetasan telur ikan maskoki tertinggi yaitu pada perlakuan D dengan tingkat penetasan $(93,67 \%)$, perlakuan C (89\%) dan perlakuan B $(77,67 \%)$ disusul perlakuan A $(66,33 \%)$. Selanjutnya data hasil penelitian dapat digambarkan ke dalam bentuk diagram di bawah ini:

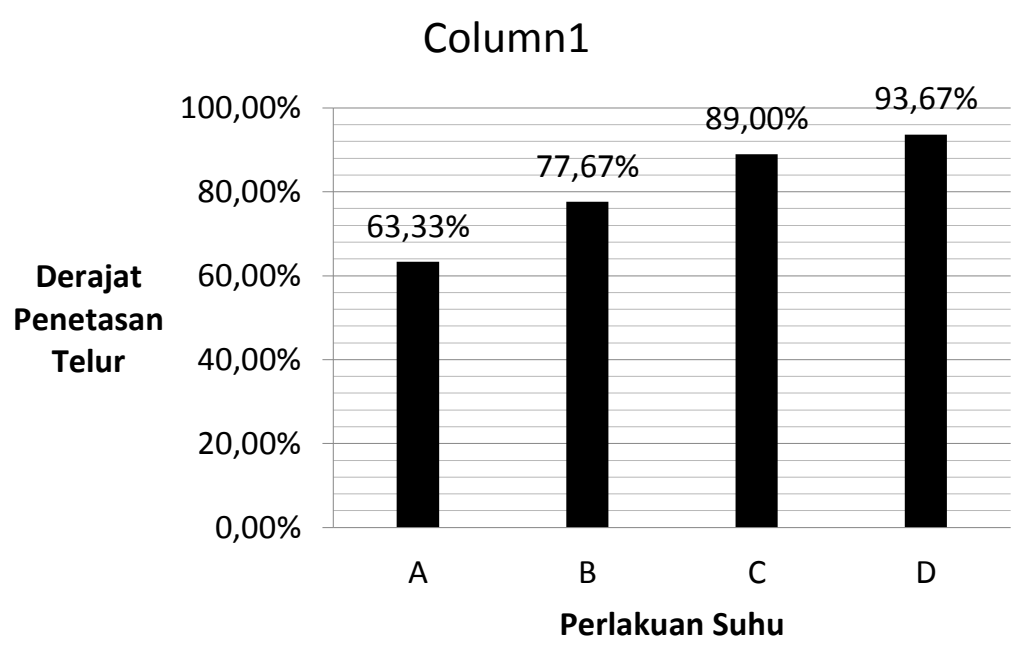

Gambar 1. Diagram Derajat Penetasan Telur Ikan Maskoki

Keterangan Gambar :

$\mathrm{A}=$ Perlakuan suhu $27^{\circ} \mathrm{C}$ dengan derajat penetasan $66,33 \%$.

$\mathrm{B}=$ Perlakuan suhu $28^{\circ} \mathrm{C}$ dengan derajat penetasan $77,67 \%$.

$\mathrm{C}=$ Perlakuan suhu $29^{\circ} \mathrm{C}$ dengan derajat penetasan $89,00 \%$.

$\mathrm{D}=$ Perlakuan suhu $30^{\circ} \mathrm{C}$ dengan derajat penetasan $93,67 \%$.

Dapat disimpulkan bahwa semakin tinggi perlakuan suhu maka derajat penetasan telur ikan maskoki akan semangkin tinggi pula, karena suhu tersebut merupakan suhu optimum untuk penetasan telur ikan maskoki. Hal ini dijelaskan [6] penetasan telur dipengaruhi oleh faktor internal berupa kerja hormon dan volume kuning telur serta faktor eksternal berupa suhu. Menurut [7] pada fase morula dan blastula telur sangat peka terhadap gangguan mekanis seperti suhu sehingga penetasan telur sebaiknya dilakukan dengan suhu yang optimal untuk perkembangan embrio. suhu mempengaruhi perkembangan dan penetasan telur, baik perkembangan maupun penetasan akan lebih cepat pada suhu panas (tinggi) dan tidak berfluktuasi, karena dapat mempercepat metabolisme dan produksi enzim pelarut/ pelunak material kulit telur. Berdasarkan dari beberapa penelitian terdahulu menunjukkan bahwa setiap jenis ikan memiliki kisaran suhu optimum yang berbeda terkait dengan perkembangan dan daya tetas telur [8]. Suhu merupakan faktor lingkungan yang dapat mempengaruhi pertumbuhan rata-rata serta menentukan waktu penetasan serta berpengaruh langsung pada proses perkembangan embrio. Kisaran suhu optimum pemeliharaan telur ikan komet (Carassius auratus auratus) adalah $22,5-29,5^{\circ} \mathrm{C}[9]$. 


\subsection{Kualitas Air}

Selama penelitian berlangsung, $\mathrm{pH}$ air dalam wadah uji rata-rata 7,0 - 7,2, menurut [11] Budhiman dan Lingga (2001) menjelaskan bahwa $\mathrm{pH}$ air sangat mendukung penetasan telur ikan mas koki adalah $\mathrm{pH} 7$ sedangkan [12] Liviawati dan Afrianto (1990) mengatakan derajat keasaman $(\mathrm{pH})$ 6,5 - 8,5 sangat cocok untuk pembenihan ikan maskoki.

[13] Sutisna dan Sutarmanto (1995) menyatakan bahwa suhu yang dibutuhkan untuk penetasan antara $25-30^{\circ} \mathrm{C}$. Pendapat ini didukung oleh [14] Syahrizal (1994) menyatakan bahwa suhu yang diperlukan oleh telur untuk menetas antara $25-30^{\circ} \mathrm{C}$. ini artinya suhu rata-rata selama penelitian yakni berkisar antara $28-32^{\circ} \mathrm{C}$ masih layak untuk penetasan telur.

Berdasarkan hasil pengukuran kualitas air yang meliputi suhu dan $\mathrm{pH}$ air pada wadah uji coba menunjukan suhu rata-rata berkisar $28-32{ }^{\circ} \mathrm{C}$, sedangkan $\mathrm{pH}$ ratarata berkisar 7,0 - 7,2. Hal ini berarti kualitas air selama penelitian berada pada kondisi yang memenuhi syarat untuk penetasan telur ikan maskoki.

\section{Kesimpulan dan Saran}

\subsection{Kesimpulan}

1. Perlakuan suhu berpengaruh sangat nyata (Highly Significant) terhadap derajat penetasan ikan maskoki (Carassius auratus Linnaeus, 1758).

2. Suhu terbaik yang menghasilkan derajat penetasan tertinggi adalah $30^{\circ} \mathrm{C}$ dengan derajat penetasan telur ikan mas koki sebesar 93,67\%.

\subsection{Saran}

Perlu dilakukan penelitian tentang pengaruh suhu dan padat tebar yang berbeda terhadap derajat penetasan telur ikan maskoki ataupun pada jenis ikan maskoki lainnya.

\section{Daftar Pustaka}

[1] S Manurung, F Basuki, dan Desrina. (2017). Pengaruh Lama Perendaman Hormon Tiroksin Terhadap Daya Tetas Telur, Pertumbuhan, Dan Kelangsungan Hidup Larva Ikan Mas Koki (Carassius auratus). Journal of Aquaculture Management and Technology, Volume 6, Nomor 4 : 202-211.

[2] DP Hartono dan N Purbosari. (2010). Perbaikan Mutu dan Peningkatan Produksi Ikan Mas Koki (Carrasius auratus) Melalui Rekayasa Set Kromosom, Jurnal Penelitian Pertanian Terapan Volume 10 nomor 3: 144149.

[3] Gracia-Lo'pez, MV, Kiewek-marti and Maldonado garci M. 2004. Effects of temperature and salinity on artificially reproduced eggs and larvae of the leopard grouper Mycteroperca rosacea. Aquaculture, 237 (1-4): 485- 498.

[4] Bagenal TB \& Braun E, 1978. Eggs and early life history. In methods for assessments of fish production in fresh water. T.B. Bagenal (Ed.) Oxford London: Blackwell Scientific Publication, pp: 165-201.

[5] Zairin, M. 2002. Sex Reversal Memproduksi Benih Ikan Jantan atau Betina. Penebar Swadaya, Jakarta.

[6] M. Zairin Jr., R. K. Sari dan M. Raswin. 2005. Pemijahan Ikan Tawes Dengan Sistem Imbas Menggunakan Ikan Mas Sebagai Pemicu,. Jurnal Akuakultur Indonesia, 4 (2): 103-108. 
Vol. 6, SNo. 2 (2019)

$\mathcal{H a l}: 45-51$

[7] Woynarovich, E and L. Horvath. 1980. The Artifisial Propagation of Warmwater fin fishes. A Manual For Extention. F.A.O Fish Tectio C. Pap (201): 183 PP.

[8] Okunsebor SA, Ofojekwu PC, Kakwi DG, Audu BS . 2015. Effect of Temperature on Fertilization, Hatching and Survival Rates of Heterobranchusbidorsalis Eggs and Hatchlings. British Journal of Applied Science \& Technology, 7(4): 372-376

[9] U Khasanah, L Sulmartiwi, dan Rr J Triastuti. 2016. Embriogenesis Dan Daya Tetas Telur Ikan Komet (Carassius Auratus Auratus) Pada Suhu Yang Berbeda. Journal of Aquaculture and Fish Health, Volume 5 Nomor 3: 108-117.

[10] AA Budhiman dan P Lingga. 2001. Maskoki. Penebar Swadaya, Jakarta. 80 Halaman.

[11] E Liviawati dan E. Afrianto. 1990. Maskoki Budidaya dan Pemasarannya. Kanisius, Yogyakarta. 112 Halaman.

[12] DH Sutisna dan R Sutarmanto. 1995. Pembenihan Ikan Air Tawar. Kanisius, Yogyakarta. 135 halaman.

[13] Syahrizal. 1994. Pengaruh Konsentrasi Malachyte Green Terhadap Penetasan Telur Ikan Lele Dumbo (Clarias gariepinus Burchell). Skripsi Program Studi Budidaya Perairan Fakultas Perikanan, Universitas Dharmawangsa, Medan. 41 halaman. 